\title{
CLASSROOM INTERACTION: TURN-TAKING AS A PEDAGOGICAL STRATEGY
}

\author{
Dr Vuyokazi Nomlomo \\ University of the Western Cape
}

This paper reports on findings of a case study which analysed classroom interaction through turn-taking in Grade 4 science lessons taught through the medium of a home language and an additional language. Data were collected by means of classroom observations in one primary school in the Western Cape, South Africa. The paper argues that, whilst knowledge of the language of learning and teaching is a basic condition for learning in the classroom, there are other factors which impact on learners' construction of knowledge during classroom interaction. It concludes that turn-taking in science teaching should go beyond the mere exchange of talk or turns to a deeper and critical interrogation of what is being taught, and how it is taught to enhance learners' scientific literacy development.

\section{Key words}

Classroom interaction, turn-taking, pedagogical strategies, home language, additional language, primary school science, scientific literacy

\section{INTRODUCTION}

The National Curriculum Statement (NCS), as implemented in South African schools, follows a constructivist approach to learning which views learners as active participants who have much to contribute to the teaching-learning process (Department of Education, 2005). It promotes interactive and learner-centred teaching approaches to produce multi-skilled, literate and independent learners (Department of Education, 2005; Gibbons, 2002; Hawkins, 2000; Eggen \& Kauchak, 1988). However, there are a number of socio-cultural factors that can either promote or hinder classroom interaction and participation. Some of these factors include language through which teaching and learning occurs, teachers' pedagogical content knowledge (PCK), the teachers' and learners' prior experiences, their behaviour, attitudes, beliefs, personalities and cultural values (Van Eerde, Hajer \& Prenger, 2008; Appleton \& Harrison, 2001; Spanneberg, 2001; Wellington \& Osborne, 2001; Eggen \& Kauchak, 1988).

Language is the most important tool in classroom interaction (Wellington \& Osborne, 2001) as it serves various roles (communicative, educational, aesthetic, cognitive, etc.), as stated in the NCS (2005). Language not only facilitates communication (verbal and non-verbal) in classroom interaction, but it also enables learners to access information in lesson content through thinking and reasoning. It encourages exchange of talk and roles and simultaneously develops learners' language skills and cognition for effective communication (Elbers, Hajer, Jonkers, Koole \& Prenger, 2008; Van Eerde, 2008; Gibbons, 2002; Donato, 2000; Hawkins, 2000; Gass \& Selinker, 1994; Ellis, 1992). In other words, it is responsible for the 
development of learners' cognitive academic language proficiency skills (CALP) which enable the learner to grasp or master academic content knowledge (Lemmer, 1996; Cummins, 1981). This implies that classroom interaction is not only a social process, but also involves a cognitive aspect, as learners negotiate meaning of the subject content (Thuraisingam, 2001; Ellis, 1992).

The role and impact of language on learners' academic performance has been extensively researched over the past two decades (Groepe, 2009; Mwishineike, 2009; Yohannes, 2009; Nomlomo, 2007; Langenhoven, 2005; Bamgbose, 2005; Heugh, 2003; Mwishineike, 2003; McKay \& De Klerk, 1996; Sentson, 1994). Most of these research studies do not focus on actual classroom interaction between teachers and learners in the classroom. The purpose of this article, therefore, is to report on findings of a case study which analysed classroom interaction through turn-taking in Grade 4 science lessons taught through the medium of a home language and an additional language respectively. The research identified different turntaking strategies employed by teachers in Grade 4 science lessons, in order to determine whether there were similarities or differences in teachers' turn-taking approaches when using two different languages of instruction in science teaching. It also investigated the impact of these turn-taking approaches on learners' construction of science knowledge and language development.

\section{TURN-TAKING AS A PEDAGOGICAL STRATEGY}

One of the key features of classroom interaction is the exchange of turns, roles and talks (conversation) between the teacher and learners and between learners themselves. Turn-taking has to do with the allocation and acquisition of turns i.e. how turns are exchanged in a talk or conversation (Hutchby \& Wooffit, 2008:49). Turn allocation is about giving turns to the next speaker(s), while turn acquisition describes how turns are received. In other words, turn acquisition determines the kind of action(s) the next speaker(s) can or should take when it is his/her turn (Koole \& Berenst, 2008:135; Koole, 2006:173).

Turn-taking as a pedagogical approach is at the core of teaching and learning in any subject. It comprises instructional and regulative components as it takes into account what kind of knowledge is to be exchanged and how it should be transmitted (Singh, Nicolson \& Exley, 2001:2). It is concerned with pedagogical content knowledge (PCK), which is an important component of the teaching-learning process as it encompasses four interrelated components, namely 'knowledge of students, knowledge of environmental contexts, knowledge of pedagogy and knowledge of subject matter' (Appleton \& Harrison, 2001:2). PCK determines the nature and quality of knowledge constructed by learners and teachers' behaviour in classroom interaction. For instance, good knowledge of subject content is associated with a more interactive teaching environment, while lack of knowledge of subject matter is associated with hostility and an authoritative relationship with the learners (Graaff \& Davidoff, 1997:105).

The most familiar turn-taking pattern in social interaction is the selection of the next speaker by the current speaker (e.g. by asking a question, by gazing towards a particular person, by addressing him/her by name) and self-selection (Liddicoat, 2007:63-64; Silverman, 1998:100). Similarly, in classroom interaction, turn-taking is usually initiated by the teacher through asking questions or giving instructions, while learners acquire or receive turns by responding to the teachers' questions or instructions (e.g. by raising hands, by answering 
questions) (Koole \& Berenst, 2008:135; Koole, 2006:169). Learner self-selection may occur, depending on the assertiveness of the learners engaged in the interaction.

There are many oral genres in classroom talk. These include activities such as giving instructions, presenting information, asking or answering questions, accepting or rejecting ideas, etc. (Thuraisingam, 2001:4). The most common turn exchange in many classrooms follows the Initiate-Respond-Feedback (IRF) exchange, where teachers initiate questions and learners have to respond to the questions (Ellis, 1992:2). The IRF exchange is associated with power relations and control (Singh et al., 2001:2) and it often restricts the learners from expressing their views and understanding of subject content, especially in classrooms where the learners are taught in an additional language. It encourages learners to repeat what the teacher says or to give chorus answers, what Brock-Utne (2006:35) refers to as 'safe talk'. This kind of interaction is associated with the transmission or traditional mode of teaching, where the teacher takes control of the lesson content and management. It is also linked to an autocratic instead of democratic mode of teaching which encourages learner creativity and helps learners to construct their knowledge through collaborative or group learning.

Whilst teacher-initiated questions are common in classroom interaction, the kinds and quality of questions asked are of importance, as they determine the kinds of responses given by learners. Explained in terms of Krashen's Input Hypothesis (Gass \& Selinker, 1994:146; Ellis, 1997:35), the quality of the input usually correlates with the quality of output in the teaching-learning process. For example, questions of low order thinking do not encourage the learners to think or to express their views; instead they may encourage learners to memorise and retrieve certain facts. To facilitate effective communication in the classroom, it is imperative that learners are provided with a challenging, comprehensible and scaffolding input and a meaningful feedback (Van Eerde et al., 2008:34; Shrum \& Glisan, 2000:3).

With regard to science teaching, there are specific skills which learners have to acquire in order to gain literacy in this subject. These go beyond the skills of recalling and reciting information to investigating, observing, measuring, reasoning and using the language of science to describe scientific concepts (Murcia, 2005:5; Reveles, Cordova \& Kelly, 2004:1112; Wellington \& Osborne, 2001:6-8). As science learning involves different forms of communication (verbal, visual, symbolic, graphical), it accommodates learners' different learning styles and abilities (Wellington \& Osborne, 2001:6). Therefore, turn-taking in science teaching and learning should go beyond verbal communication to include interactive and learner-centred approaches that will develop learners' critical thinking, questioning and practical skills, which are necessary for science knowledge construction. In light of the above, this case study addresses the following research questions:

(i) What turn-taking approaches underpin teachers' and learners' interaction in Grade 4 science lessons?

(ii) How do these turn-taking strategies impact on the teaching and learning of science at Grade 4 level?

(iii) What are the similarities and differences in turn-taking patterns when learners are taught in their home language and in an additional language? 


\section{RESEARCH DESIGN AND PARTICIPANTS}

According to Henning, Van Rensberg \& Smit (2004:5), qualitative research examines the qualities, characteristics or properties of a phenomenon for better understanding and explanation. This research study followed a qualitative case study design in order to have an understanding of how turn-taking is used as a teaching strategy at Grade 4 level. The research was conducted in an underprivileged primary school in a black township of Cape Town. The school is situated in a low socio-economic environment, with surrounding informal settlements (shacks) and high rates of unemployment, poverty and crime. All teachers and learners of this school are home language speakers of isiXhosa. English is taught as an additional language and is also used as the medium of instruction from Grade 4. Due to the growing demand for scientific, technological and sustainable development (Murcia, 2005:2), Grade 4 science was chosen as a subject which lays a foundation of science education.

The study employed a purposive sample which comprised two (female) teachers and 73 Grade 4 learners. Two groups of learners were involved in the research study: 40 of them were taught the same science lessons through the medium of their home language (isiXhosa) while 33 of them were taught in an additional language (English). Both teachers who participated in the study had a two-year professional qualification, the Primary Teachers' Certificate (PTC) which they obtained in the 1970s and 1980s respectively. The qualification was designed for lower primary school teachers (Grades 1 to 4) with no subject specialisation.

For the purpose of this study, the teachers received special training in the form of workshops, in order to develop their science content knowledge and to enhance their pedagogical knowledge. The workshops were facilitated by a science education specialist and they focused on the science subject content and the various teaching approaches that could be used in science lessons. The workshops recommended adequate planning and preparation, innovativeness, as well as learner-centred approaches such as experiments and projects. The teachers attended four workshops altogether which corresponded with the curriculum modules, and were expected to apply the new knowledge and teaching strategies in their own science classrooms.

\section{DATA COLLECTION}

Classroom observations were used as the main tool of data collection in this study. Four Grade 4 science lessons were observed: two were taught through the medium of English and the other two were taught through the medium of isiXhosa. The lesson topics were the same. The first two lessons focused on useful animals (Izilwanyana eziluncedo/Useful animals) and the other two lessons dealt with types of energy with emphasis on electric and light energy. The four observed lessons took approximately 45 minutes each.

Research ethics were considered in that permission was sought from the Western Cape Education Department (WCED), the school, teachers, parents and learners, to conduct classroom observations. All the participants were informed of their rights (such as voluntary participation, confidentiality, respect) during the data collection phase. With the permission of the teachers, the lessons on which this article reports were audio- and video-recorded and later transcribed by the researcher in order to identify turn-taking patterns.

Field notes were also used to keep a record of what was observed and heard during data collection. Data analysis focused on how teachers initiated turns and how learners accepted 
turns (i.e. turn exchange). It also identified common types of turn-taking strategies in the two classrooms. This article presents some excerpts of the written transcriptions of the two lessons.

Although this case study was limited by the number of participants and lessons, it presents an 'opportunity to learn' (Fouche, 2005:272) from this particular case, and it affords an opportunity to have a better understanding of how turn-taking can be used to enhance teaching and learning in this particular context.

\section{RESEARCH FINDINGS}

Common patterns emerged from turn-taking in the two science lessons offered in English and isiXhosa respectively. In other words, there was no difference in the manner in which turntaking occurred in the two classrooms with different languages of instruction. The results show that both teachers used common strategies to alternate turns with their learners. The most common turns given to learners in both classes were in the form of questions, choral answers, teacher monologues and repetition of certain lesson concepts. Some lesson fragments from the four lessons have been chosen to illustrate the different turns given in the two lessons (English and isiXhosa). The fragments have been selected to show where turns are completed, as well as the turn transition points where turn exchanges occurred.

\section{QUESTIONS IN TURN EXCHANGE}

Pedagogically, questioning is a teaching, learning and assessment technique. It is one of the turn-allocation strategies whereby the current speaker selects the next speaker (Liddicoat, 2007:63; Silverman, 1998:100). The general pattern emerging from the analysed data is that both teachers, irrespective of the language of instruction, allocated turns to learners through questioning. For example, in Lesson 1A below the first turn given to learners is in the form of a question (line 1) and the learner responds in a short sentence (line 2).

\section{LESSON 1A: ISIXHOSA}

\begin{tabular}{|c|c|c|}
\hline 1 & Teacher & $\begin{array}{l}\text { Ziintoni ezenziwa ngofele? } \\
\text { [What things are made from skin?] }\end{array}$ \\
\hline 2 & Lulu & $\begin{array}{l}\text { Yiwulu, Miss } \\
\text { [It is wool, Miss] }\end{array}$ \\
\hline 3 & Teacher & $\begin{array}{l}\text { Ngofele. Izinto ezenziwe ngofele. } \\
\text { Akakho umntu onokuqaja into } \\
\text { esinokuyenza ngofele? } \\
\text { [With the skin. Things made of skin. Is } \\
\text { there someone who can guess what we } \\
\text { make from the skin?] }\end{array}$ \\
\hline 4 & Zola & $\begin{array}{l}\text { Igubu, Miss } \\
\text { [A drum, Miss] }\end{array}$ \\
\hline 5 & Teacher & $\begin{array}{l}\text { Igubu .... Very good! } \\
\text { [A drum.... Very good!] }\end{array}$ \\
\hline
\end{tabular}




\section{LESSON 1B: ENGLISH}

10

11

12

13

14

15

16

17

18

19
Teacher

Bhongo

Teacher

Siphokazi

Teacher

Anele

Teacher

Lutho

Teacher

Joy
T: Give me an example of any domestic animal that you know. (She throws a ball to one of the learners to catch and answer)

Dog

Pass the ball over.

(Learner passes the ball to another learner)

Sheep

Pass it on.

(Quiet)

(Teacher moves on and asks another question) Cow supplies us with dash, dash, dash for the babies.

Milk

With milk for the babies. Pass it over. Milk processed provides us with $\boldsymbol{d a s h}$, dash, dash.

Cheese

In Lesson 1B, the teacher introduces a question statement (line 10) which demands a oneword answer from the learner (in line 11). In both lessons, some of the questions promote guessing and reinforce brief or one-word answers. For example, in Lesson 1A (line 3) the question encourages learners to guess. Likewise, in Lesson 1B the questions require oneword answers (e.g. filling in missing words) as shown in lines 11, 13, 17 and 19. In both lessons, the interaction, or talk, continues as the teachers initiate or introduce more questions to the learners with no feedback or consolidation of the learners' responses.

Although the focus of this paper is not about the analysis of the quality of questions given to learners, in pedagogical terms most of questions are not cognitively demanding for effective learning. We find the same kind of questions in both groups; only the language of instruction is different. This suggests that the change of language of instruction does not necessarily impact on the quality of questions allocated for turn exchange by the teachers.

\section{CHORAL TURNS}

Choral responses from the learners were common in both lessons. The choral answers were responses to teacher statements and questions (i.e. they served as turn exchanges between the teacher and the learners). There is no bidding or invitation for turns by the learners. The syntactical structure and the tone of the teachers' utterances reinforce choral answers from the learners, as reflected in fragments of Lessons $1 \mathrm{C}(34,36)$ and $1 \mathrm{D}(28,30,32)$ below. 


\section{LESSON 1C: ISIXHOSA}

33

35

36
Teacher

Learners

Teacher

Learners
Iiglavu...Izingxobo zezandla. Siyazazi sonke iiglavu.

[Gloves...Hand gloves. We all know the gloves.] Yes, Miss!

Igusha iyatya njengokuba nathi sisitya. Itya umngqusho? [A sheep eats as we also eat. Does it eat samp?] Hayi Miss! [No, Miss!]

\section{LESSON 1D: ENGLISH}

27
Teacher

Learners

Teacher

Learners

Teacher

Learners
Is a horse a mammal?

Yes, Miss.

People are mammals. Do you agree?

Yes, Miss.

Sisekunye bantu?

[Are we still together, people?]

In Lesson 1D above, the question in line 27 assesses learners' knowledge and the response in line 28 displays what the learners know. In line 29 the teacher presents a statement and learners have to agree or disagree with the statement (in line 30). This kind of questioning promotes guessing.

The choral answers given in Lesson $1 \mathrm{C}$ above confirm what the teacher is saying, while at the same time checking what the learners know about the lesson (lines 33 and 35). Similarly, in (1D) the teacher checks her learners' comprehension (line 31) and the choral answer is a means of assuring the teacher that they understand the lesson (line 32). It is interesting to note that the teacher switches from English to the learners' home language in line 31. This could be a way of assuring that everyone in the class understands the lesson by making use of a language known by all the learners, so that there could be no misunderstandings before the teacher moves to the next turn.

From the learner perspective, choral turns affirm teacher statements while teachers trigger choral answers to confirm or consolidate certain aspects of the lesson content and to ascertain that learners understand the lesson. Teachers also use them as tools for classroom management (e.g. the teacher gives instructions and learners confirm that they follow the given instructions). The negative side of choral answers, however, is that some learners may go with the flow, and the teacher may think that everybody understands the lesson. Thus Brock-Utne (2006:35) refers to chorus answers as 'safe talk' for both the teacher and the 
learners, in that the teacher accepts the answers without finding out whether every learner understands the lesson. Through safe talk the learners do not show or express what they understand or do not understand. Hence there is no feedback following the choral responses as it appears in both Lessons 1C and 1D.

\section{TEACHER MONOLOGUES AND BRIEF LEARNER TURNS}

The analysed data show long teacher turns and brief learner turns. The teachers' long turns become monologues; they talk alone, without involving the learners. Although there is an exchange of turns at some points, the long 'teacher talk' limits elaborated or long turns from learners. Due to the limited learner involvement in the talk, the lesson becomes more teachercentred than learner-centred (e.g. Lessons 2A and 2B).

\section{LESSON 2A: ISIXHOSA}

16

17

18

19

20

21

22

23

24

25

26
Teacher

Teacher

Teacher

Learners

Teacher:

Teacher:

Teacher

Teacher

Teacher

Teacher

Teacher

Teacher

Learners

Teacher
Zaphucuka izinto

[Things improved]

Kwavela mntu uthile ekuthiwa nguThomas Edison

[Someone called Thomas Edison appeared].

Ngubani loo mntu?

[Who is that person?]

Thomas Edison (chorus)

(Writes on the board: Thomas Edison)

Zonke izinto ziyenziwa

[Everything is invented].

Ayithi into ize ibekho, ibekhona nje

[Nothing just exists].

Nale tshokhwe ndiyiphetheyo kukhona umntu owacingayo ukuba ze kubhalwe ebhodini into ebonwa ngabantwana kufuneka kubekho itshokhwe.

[Even this chalk I am carrying, there is a person who thought that in order to write something to be seen by children on the board, the chalk should be available].

Kukhona umntu owayenzayo [There is a person who made it]

Sikhumbule ukuba nezi khamera sizisebenzisayo kukhona abantu abacingayo ukuba makubekho iikhamera [We must remember that even these cameras we use, there are people who thought that there should be cameras]

kuzofotwa ukuze kuphume ubuso bakho

[to take photographs to show your face]

Okay?

Yes Miss (chorus)

Ngoku apha lona umntu ...

[Now, here this person]... 
Teacher Kukho igama esiNgesini, ...

[There is a term in English...]

28 Teacher Sithetha ngoku 'inventa'

[We are talking about inventing].

Wa-inventa

[He invented] (Teacher writes the word down; 'inventa' -to invent).

Teacher

Uku-inventa ke, ... kuthiwa loo mntu wacinga,...

Teacher

[To invent,... it is said that this person thought,...]

Teacher

akagqiba ukucinga, wenza umbane

[and did not only think, but made electricity].

33 Teacher

Wacinga wenza umbane

[He thought and made electricity]

Teacher

Ngoku wacinga ngeench
umsebenzi ukhawuleze

[Now he thought of shorter ways to make things work faster].

Wacinga ngokuba makubekho umbane

Teacher

[He thought that there should be electricity].

Learners

Loo mntu lowo sithi ngubani?

[What do we call that person?]

Teacher

Thomas Edison (chorus)

Learners

Ngubani loo mntu

[Who is that person]?

Thomas Edison (chorus)

In Lesson 2A above the teacher starts her turn in line 13 when she talks about the person who invented electricity in line 14. There is a turn exchange in line 15 where she asks a question, although she has already provided the answer in line 15 (Thomas Edison). Her question serves to check her learners' listening skills, and learners respond in the form of a chorus (line 16). The teacher continues with her talk from line 18 to 24 and she checks her learners' attention again in line 24 (Okay?). This question does not have anything to do with the lesson but the learners' choral answer (in line 25) confirms their attention, although they are passive listeners. The teacher's explanation continues from line 26 and there is a turn transition at line 34 where the teacher repeats the question she started with at line 15 . The question is not cognitively challenging and it does not provide enough opportunity for learners to use the language.

\section{LESSON 2B: ENGLISH}

\section{1}

42

43

44

45

46

47

48
Teacher

Learners (all)

Teacher

In that orange there is stored energy.

Where does it come from?

It came from.....? (pointing at the picture of the sun)

The sun (chorus)

If you wake up early in the morning.

I don't want to mention names... for those who are always late-comers.

Sometimes you wake up and find out that everybody is not here.

My mother didn't wake me up 
You wake up

Before you do anything, you say: 'I'm late' but you don't have a watch,...

You run outside. see... you see light.

The light comes from the sun.

We see a similar pattern in Lesson $2 \mathrm{~B}$, above, in which the teacher gives a long explanation about the light energy. The explanation follows a brief response from learners in line 44 . Although the teacher's explanation is appropriate and scaffolds learners in making sense of the lesson content, it makes her turn longer, and it limits the learners' participation in the lesson as it triggers brief answers from the learners.

The teacher also switches from English to the learners' home language (isiXhosa), which is also her home language (in line 56) where she explains the main concept of the lesson in the learners' home language (ubushushu/heat). Code switching could be explained in terms of the teacher's language proficiency, but the way in which she uses it shows that she is comfortable with the language and realises that she needs to mediate learning in a language that all learners know well. It also shows that the teacher has some proficiency in the two languages (isiXhosa and English). The teacher's turn ends with a less challenging question (in line 57) which has the potential of leading to another long turn by the teacher as the learners give a choral answer in line 58.

\section{REPETITION IN TURN EXCHANGE}

Repetition is also one of the common patterns of turn-taking in the two classes, as reflected in Lessons $3 \mathrm{~A}$ and $3 \mathrm{~B}$ below. However, there is a difference in the manner in which repetition is conducted and managed in the two classes.

\section{LESSON 3A: ISIXHOSA}

Teacher

Learners

Teacher
(Showing a round shape with her fist). Sithi kaloku into engqukuva yinto enje.

[We say a round thing is like this.] Injani le nto ndiyibonisileyo? [How is the thing I have showed?] Ingqukuva. [It is round.] Injani?

[How is it?] 


\begin{tabular}{|c|c|c|}
\hline 124 & Learners & $\begin{array}{l}\text { Ingqukuva. } \\
\text { [It is round.] }\end{array}$ \\
\hline 125 & Teacher & $\begin{array}{l}\text { Injani? } \\
\text { [How is it?] }\end{array}$ \\
\hline 126 & Learners & $\begin{array}{l}\text { Ingqukuva. } \\
\text { [It is round.] }\end{array}$ \\
\hline & Teacher & $\begin{array}{l}\text { Injani? } \\
\text { [How is it?] }\end{array}$ \\
\hline & Learners & $\begin{array}{l}\text { Ingqukuva. } \\
\text { [It is round]. }\end{array}$ \\
\hline & Teacher & $\begin{array}{l}\text { Injani? } \\
\text { How is it? }\end{array}$ \\
\hline & Learners & $\begin{array}{l}\text { Ingqukuva. } \\
\text { [It is round.] }\end{array}$ \\
\hline & Teacher & $\begin{array}{l}\text { Yintoni umzekelo wento engqukuva? } \\
\text { [What is an example of a round thing?] }\end{array}$ \\
\hline & Zola & $\begin{array}{l}\text { Ngamehlo enkomo. } \\
\text { [It is the cow's eyes.] }\end{array}$ \\
\hline
\end{tabular}

In Lesson 3A (isiXhosa) above, learners are encouraged to repeat certain concepts in order to grasp them. The repeated concepts are in a one-word format, and they do not actually display the learners' overall comprehension of the lesson content, as learners are asked to repeat the same concept over and over. For example, the teacher started her turn in line 120 when she demonstrated the round shape of the eyes. To check her learners' understanding she asks a question in line 121 and she gets a correct response in line 122. To emphasise the concept (round) she asks the same question five times (lines 123 to 129) and the learners have to give the same answer five times as well. While this kind of repetition facilitates talk exchange between the teacher and her learners, it does not promote active learning.

In Lesson 3B (English) below, we see a different kind of repetition. The teacher repeats the learners' responses in order to confirm the correctness of the answers. The turns are given to several learners $(95,97,99,101,103$ and 105) and turn transitions are observed in lines 102 and 104. The turns allocated to learners, however, are very short, due to the kinds of questions asked by the teacher.

\section{LESSON 3B: ENGLISH}

$\begin{array}{lll}94 & \text { Teacher } & \begin{array}{l}\text { Give me other examples of mammals that you } \\ \text { know. }\end{array} \\ 95 & \text { Sisa } & \text { Dog } \\ 96 & \text { Teacher } & \text { Dog } \\ 97 & \text { Vusi } & \text { Cow } \\ 98 & \text { Teacher } & \text { Cow } \\ 99 & \text { Zizipho } & \text { Sheep }\end{array}$




$\begin{array}{lll}100 & \text { Teacher } & \text { Sheep } \\ 101 & \text { Sisanda } & \text { Cat } \\ 102 & \text { Teacher } & \text { Cat. What do we call the father sheep? } \\ 103 & \text { Lucy } & \text { Ram } \\ 104 & \text { Teacher } & \text { Ram. Where do we get sheep? } \\ 105 & \text { Sabelo } & \text { Namibia } \\ 106 & \text { Teacher } & \text { Namibia }\end{array}$

\section{DISCUSSION}

The findings of the study show four common turn-taking strategies in the two classrooms: questions, choral answers, teacher monologues and repetition of certain lesson concepts by learners. Although these turn-taking approaches are relevant in terms of interaction, teaching and assessment in the classroom, they do not promote learner creativity and participation for better knowledge construction. These turn-taking approaches can be associated with power relations and certain socio-cultural factors in a number of ways.

Firstly, with regard to power relations, both teachers display an authoritarian (autocratic) relationship with their learners, as they always initiate turns and select learners to respond to their questions, without providing opportunities for learners to initiate turns or to express their views. This kind of interaction is associated with the Initiate-Response-Feedback (IRF) pattern mentioned previously, by which teachers always initiate questions and learners are expected to respond only to the questions given to them. In this kind of interaction, the teacher is the only active participant, while the learners remain passive recipients of knowledge (Martin, Sexton, Wagner \& Gerlovich, 1994:49) who 'learn to obey, be quiet, to become indifferent and apathetic' (Brock-Utne, 2006:30). This approach is teacher-centred and it encourages rote learning (Ellis, 1992:2; Tsui, 1996:149). The power distance between teachers and learners may lead to fears and anxiety, which may have negative effects on learner participation during the teaching-learning process.

Secondly, teachers' previous experiences and beliefs influence their classroom practices and interaction (Hajer \& Koole, 2008:19); Spanneberg, 2001:1; Eggen \& Kauchak, 1988:8). For example, teachers who hold socio-constructivist beliefs about learning often engage their learners actively in their teaching (through collaborative interaction and engagement), while teachers who believe in transmission teaching often employ less interactive teaching strategies and this leads to more teacher talk and less learner talk and participation. In this study, the teachers' behaviour reflects their beliefs in transmission teaching as they allocate themselves long turns (monologues) while their learners are given short turns that inhibit them from playing an active role in the lessons. Korthagen and Kessels (1999:5) refer to the influence of teachers' previous experiences on their classroom behaviour and practices as the 'transfer problem', which can either enhance or hinder the teaching-learning process. 
Thirdly, teachers' limited subject content knowledge manifests itself as limited pedagogical content knowledge (Appleton \& Harrison, 2001:1). In this study, teachers' limited science content knowledge had an influence on the turn-taking process in their classrooms although the teachers had received special in-service training in science teaching. The study shows that the teachers' workshops which were provided for intervention purposes did not have a positive influence on the teachers' PCK. Given the short duration of these workshops and the teachers' prior knowledge and experiences (Korthagen \& Kessels, 1999:5), one may not expect a drastic change in teachers' PCK. This research finding remains an interesting area for further research which cannot be fully addressed in this article. However, it can also be associated with the teachers' schooling background and their learning styles, as suggested in Korthagen and Kessels' (1999:5) notion of the transfer problem. There is a correlation between teachers' 'preferred way of teaching' (Korthagen \& Kessels, 1999:6) and the way in which they themselves learned at school. Teachers who experienced active involvement in their learning are more likely to facilitate active learning in their teaching (Korthagen \& Kessels, 1999:6).

Fourthly, the kinds of turns allocated to learners in the two science classrooms can be explained in terms of the Input Hypothesis (Ellis, 1992:2) which emphasises the relationship between the quality of the input and the output. As mentioned previously, if the input is of high quality, it is likely that the output will be of good quality too, and vice versa. With regard to turn-taking, the long teacher monologues and less challenging questions reinforced learners' brief and one-word responses (output) and choral answers in this research. This is contrary to what science education seeks to achieve, as it requires good communication skills to facilitate scientific discourse (Tom, 2002). As science education involves learning the language of science, which is complex, abstract and highly specialised (Jones, 2000; Puhl, 2000; Monk \& Dillon, 1995), it is crucial that learners are exposed to cognitively challenging activities and exploratory talk to enhance their understanding of scientific terms while developing their language skills. This is possible if classroom interaction encourages learners to use the language of science (in English or isiXhosa) through talking, reading and writing.

Finally, whilst it is logical to assume that teaching and learning in a home language would lead to more interactive turn-taking approaches in the classroom as teachers and learners communicate in a familiar language, such an assumption may be misleading. The research findings of this study show that there is no difference in the nature of turns allocated to learners when they are taught in their home language or in an additional language. There are other factors that may have an influence on classroom interaction, such as the teachers' initial training, their pedagogical strategies, and confidence levels.

In conclusion, this study has shown that turn-taking is a complex process which is influenced by various factors including classroom power relations, teachers' PCK, attitudes, beliefs, etc. With regard to science teaching, turn-taking should consider the different science skills that learners need in order to attain scientific literacy. It should therefore go beyond the mere exchange of talk or turns to a deeper and critical interrogation of what is being taught, and how it is taught, to enhance the development of scientific literacy. This calls for teacher development programmes (both pre-service and in-service) that focus on teachers' knowledge of subject content and pedagogical content and on reflective practices, along with adequate resources and support from other colleagues and subject specialists. It is important that researchers and education officials prioritise classroom interaction and support in order to enhance teachers' pedagogical strategies in all learning areas. 


\section{REFERENCES}

APPLETON, K \& A HARRISON. 2001. Outcomes-based science units that enhance primary and secondary science teachers' PCK. Paper presented at the Australian Association for Research in Education (AARE) Conference, Fremantle.

BAMGBOSE, A. 2005. Mother tongue education: Lessons learnt from the Yoruba experience, in B Brock-Utne \& Hopson, RK. (Eds), Languages of instruction for emancipation: Focus on postcolonial contexts and considerations. Dar es Salaam: Mkuki na Nyota Publishers. 231-255.

BROCK-UTNE, B. 2006. Learning through a familiar language versus learning through a foreign language - a look at some secondary school classrooms in Tanzania. In: Brockne, B, Z Desai \& M Qorro (Eds), Focus on fresh data on the language of instruction debate in Tanzania and South Africa. Cape Town: African Minds. 19-40.

CUMMINS, J. 1981. Empirical and theoretical underpinnings of bilingual education. Journal of Education, 163(1):16-29.

DE KLERK, V. 2000. To be Xhosa or not to be Xhosa...That is the question. Journal of multilingual and multicultural development, 21 (3):198-215.

DEPARTMENT OF EDUCATION. 2005. National Curriculum Statement (NCS). Pretoria.

DONATO, R. 2000. Sociocultural contributions to understanding the foreign and second language classroom. In Lantolf, JP (Ed), Sociocultural theory and second language learning. New York: Oxford University Press. 27-50.

EGGEN, P. \& D. KAUCHAK. 1988. Strategies for teachers. USA: Prentice Hall.

ELBERS, E, M HAJER, M JONKERS, T KOOLE \& J PRENGER. 2008. Instructional dialogues: Participation in dyadic interactions in multicultural classrooms. In Deen, J, M Hajer \& T Koole (Eds), Interaction in two multicultural mathematics classrooms. Amsterdam: Aksant. 139-170.

ELLIS, R. 1992. Learning to communicate in the classroom: A study of two language learners' requests. Cambridge: Cambridge University Press.

ELLIS, R. 1997. Second language acquisition. New York: Oxford University Press.

FOUCHE, CB. 2005. Qualitative research designs. In De Vos, AS, H Strydom, CB Fouche \& CSL Delport (Eds), Research at grass roots ( $3^{\text {rd }}$ edition). Pretoria: Van Schaik.

GASS, SM \& L SELINKER. 1994. Second Language Acquisition: An introductory course. New Jersey: Lawrence Erlbaum.

GIBBONS, P. 2002. Scaffolding learning. Portsmouth: Heinemann.

GRAAFF, J \& S DAVIDOFF. 1997. Conclusion: Different questions of a different kind. In Graaff, J, B Parker, S Davidoff, K Collett \& P Kabali-Kagwa (Eds), Teaching in the gap: Implementing Education Policy in South Africa in the nineties. Cape Town: Via Afrika.

GROEPE, L. 2009. English as a medium of instruction in Grade 11 Geography: A case of a secondary school in the Western Cape. Unpublished M.Ed. thesis. Cape Town: University of the Western Cape.

GROSSER, M \& DE WAAL. 2008. Recentering the teacher: from transmitter of knowledge to mediator of learning. Education as change,. 12(2):41-57. 
HAJER, M \& T KOOLE. 2008. Introduction. In Deen J, M Hajer \& T Koole (Eds), Interaction in two multicultural mathematics classrooms. Amsterdam: Aksant. 1-7.

HARLEN, W \& A QUALTER. 2004. The teaching of science in primary schools $\left(4^{\text {th }}\right.$ edition). London: David Fulton.

HAWKINS, M. 2000. The reassertion of traditional authority in a constructivist pedagogy. Teaching Education, 11(3):279-296.

HENNING, E, W VAN RENSBURG \& B SMIT. 2004. Finding your way in qualitative research. Pretoria: Van Schaik.

HEUGH, K. 2003. The case against bilingual and multilingual education in South Africa: Laying bare the myths. In Heugh, K. Language policy and democracy in South Africa. Doctoral dissertation. Sweden: University of Stockholm.

HUTCHBY, I \& R WOOFFIT. 2008. Conversation analysis ( $2^{\text {nd }}$ edition). Cambridge: Polity Press.

JONES, C. 2000. The role of language in the learning and teaching of science. In Monk, M \& J Osborne (Eds), Good practice in science teaching. Philadelphia: Open University Press. 88-103.

KOOLE, T. 2006. An interactional perspective on the language of instruction. In Brock-Utne, B, Z Desai \& M Qorro (Eds), Focus on fresh data on the language of instruction debate in Tanzania and South Africa. Cape Town: African Minds.

KOOLE, T \& J BERENST. 2008. Pupil participation in plenary interaction. In Deen, J, M Hajer \& T Koole (Eds), Interaction in two multicultural mathematics classrooms. Amsterdam: Aksant. 107-138.

KORTHAGEN, FAJ \& PAM KESSELS. 1999. Linking theory and practice: Changing the pedagogy of teacher education. Educational Researcher, 28(4):4-17.

LANGENHOVEN, KR. 2005. Can mother tongue instruction contribute to enhancing scientific literacy? A look at Grade 4 Natural Science classroom. In Brock-Utne, B, Z Desai \& M Qorro (Eds), LOITASA Research in Progress. Dar-es-Salaam: KAD Associates.

LEMMER, EM. 1996. Selected realities in South African schools: Problems and prospects. In Engelbrecht, P, SM Kriegker \& MI Booysen (Eds), Perspectives on learning difficulties. Pretoria: Van Schaik. 312-323.

LIDDICOAT, AJ. 2007. An introduction to conversational analysis. London: Continuum.

MARTIN-HANSEN, L. 2002. Defining Inquiry. The Science Teacher, 69(2):34-37.

MARTIN, JRE, C SEXTON, K WAGNER \& J GERLOVICH. 1994. Teaching science for all children. Boston: Allyn \& Bacon.

MCKAY, S \& V DE KLERK. 1996. The effect of second language education on academic achievement in a Std 10 History class. Language Matters: Studies in the languages of Africa, 27(1): 197 - 221.

MONK, M. \& J DILLON. 1995. National Research Council (NRC). Learning to teach science: For student teachers and mentors. London: The Falmer Press.

MURCIA, K. 2005. Science for the $21^{\text {st }}$ century: Teaching for scientific literacy in the primary classroom. Paper presented at the CONASTA54. University of Melbourne. 
MWINSHEIKHE, HM. 2003. Using Kiswahili as a medium of science teaching in Tanzanian Secondary Schools. In Brock-Utne, B, Z Desai \& M Qorro (Eds), Language of instruction in Tanzania and South Africa (LOITASA). Dar es Salaam: E \& D Limited. 129-139.

MWINSHEIKHE, HM. 2009. Spare no means: Battling with the English/Kiswahili dilemma in Tanzania secondary school classrooms. In Brock-Utne, B \& I Skattum (Eds), Languages and Education in Africa. United Kingdom: Symposium Books. 223-234.

NOMLOMO, VS. 2005. Instructional approaches in Science: A case of two Grade 4 classes in the Western Cape, South Africa. In Brock-Utne, B, Z Desai \& M Qorro (Eds), LOITASA Research in Progress. Dar es Salaam: KAD Associates. 256-280.

NOMLOMO, VS. 2007. Science teaching and learning through the medium of English and isiXhosa: A comparative study at two primary schools in the Western Cape. Unpublished Doctoral thesis. Cape Town: University of the Western Cape.

PUHL, CA. 2000. Teaching the language of Science. Workshop given at the Science and Technology Conference. Cape Town, 22-24 September.

REVELES, JM, R CORDOVA \& GJ KELLY. 2004. Science literacy and identity formulation. Journal of Research in Science Teaching, 41(10):1111-144.

SCHEGLOFF, EA. 2007. Sequence Organization in interaction. Cambridge: Cambridge University Press.

SENTSON, C. 1994. The effect of language of presentation on the pupils' performance in a Mathematics test. South African Journal of Education, 14 (3):109 - 113.

SHRUM, J. \& EW. GLISAN (Eds.) 2000. Teacher's Handbook - contextualized language instruction ( $2^{\text {nd }}$ edition). USA: Heinle \& Heinle.

SILVERMAN, D. 1998. Social Science and Conversational Analysis. New York: Oxford University Press.

SINGH, P, H NICOLSON \& B EXLEY. 2001. Teacher Talk and Classroom Practice: An analysis of the Constitution of Pedagogic Identities. Paper presented at the Australian Association for Research in Education (AARE) Conference, Fremantle.

SPANNEBERG, R. 2001. Teachers'Beliefs and Practices related to a Professional Development Programme in South African Rural Schools. Paper presented at the Australian Association for Research in Education (AARE) Conference, Fremantle.

OSWALD, M \& E SWART. 2008. How teachers navigate their learning in developing inclusive learning communities. Education as change, 12(2): 91-108.

THURAISINGAM, P. 2001. Language use and Interaction in the History Classroom. Paper presented at the Australian Association for Research in Education (AARE) Conference, Fremantle.

TIMONS, M. 2003. Inquiring minds. The Science Teacher, 70(7):31-37.

TOM, E. 2002. Science and communication. The Science Teacher, 69(8):39-41.

TSUI, ABM. 1996. Reticence and anxiety in second language learning. In Bailey, KM. \& Nunan, D (Eds), Voices from the language classroom. Cambridge: Cambridge University Press. 
VAN EERDE, D, M HAJER \& J PRENGER. 2008. Promoting mathematics and language learning in interaction. In Deen J, M Hajer \& $\mathrm{T}$ Koole (Eds), Interaction in two multicultural mathematics classrooms. Amsterdam: Aksant. 31-68.

WELLINGTON, J \& J OSBORNE. 2001. Language and Literacy in Science Education. Philadelphia: Open University Press.

YOHANNES, MAG. 2009. Implications of the use of mother tongues versus English as languages of instruction for academic achievement in Ethiopia. In Brock-Utne, B. \& I Skattum (Eds), Languages and Education in Africa. United Kingdom: Symposium Books.

\section{BIOGRAPHICAL NOTE}

Vuyokazi Nomlomo is a senior lecturer in the Faculty of Education at the University of the Western Cape, South Africa. She specialises in Language Teaching with a special focus on African Languages for teacher development at the pre-service and in-service levels. Her research interests are in the following broad areas: language in education, linguistics, multilingualism, teacher education, classroom interaction and gender equality, poverty in education. E-mail: vnomlomo@uwc.ac.za 